UDC 161.3

BILETSKY VITALIY,

Vasyl' Stus Donetsk National University (Vinnytsia, Ukraine)

e-mail: beleckii-vitalii@mail.ru, ORCID0000-0003-2818-131X

\title{
POLITICAL AGITATION AND STATE OF MENTAL MATURITY OF THE DOMESTIC SOCIETY
}

\begin{abstract}
In the article the author develops a typology of accents of the influence on the contemporary domestic electorate during the election of the President of Ukraine in the spring of 2019. This purpose is achieved by involving socio-philosophical methodology and the achievements of a psychoanalytic philosophical paradigm. There are four types of accents that were observed during the race. Politicians of the first accent sought to influence the critical thinking of the electorate. The second group of politicians sought to exploit a scientifically constructed myth - about themselves or "almost" about themselves. The third group focused on individual myths that were not united by a holistic political myth. The fourth group appealed to the trust that was unreasonable. Thus, political agitations form a continuum - from attempts to influence solely voter's rationality to counting on the resonance of their subconscious mythological architectonics. In addition, it is concluded that the politicians of near future should flexibly involve all constructive from this continuum in order to strengthen their own positive influence on the electorate. In this context, the modern politicians should focus on political mythmaking necessarily, because it is scientifically correct. The author of the article shares the view of those classics of philosophy who see the basis of any cultural activity in myth. Of course, a rational component of political agitation should be present. For example, there should be very rationally compiled (and executed) political program.
\end{abstract}

Key words: elections of the President of Ukraine; electorate; rationality; logic; political mythmaking; mythologeme.

\section{Introduction}

The course of the current presidential campaign appropriately actualized the political advertising activities of famous domestic personalities, and suddenly brought to the political arena obvious newcomers. It is clear that in an effort to increase their electoral sympathies, all of them, monitoring intermediate results, combined various methods of influence on voters at different stages of the race. An appealing could lean towards only two polar properties of the psychology of Ukrainian citizens - either to their rationality, logic, or to the complex of numerous irrational properties of the psychics - instincts, faith, emotions, mythological archetypal foundations of the unconscious.

In our previous works on this subject we analyzed the topic of the formal-logical maturity of the communicative flows of politicians of the past, highlighting various, sometimes very rude, logical and rhetorical mistakes that were often made by well-known personalities of the Ukrainian politics of the recent past (Biletskyy, 2006 and 2010). Therefore, it was concluded that political players, possibly intentionally, to some degree discrediting their own intellectual level and focusing not on the rationality of a critical-thinking voter, achieved victory thanks to the support of the Ortega y Gasset's "mass man".

The current candidates for the office of President of Ukraine, obviously, also wanted to succeed and realized that the Ukrainian society, like any other, is not homogeneous in terms of the level of criticality of information perception. Therefore, a number of contenders, probably, broadcasted the text-visual array, which was immature from the point of view of formal logic and traditional scientific rhetoric, naturally and purposefully, counting on the emotionally-affective resonance of the mentally depleted part of electorate.

Based on this assumption, we thus formulate the purpose of our research: to typologize flows of modern political propaganda rhetoric by the criterion of rational (formal-logical) maturity or orientation towards other irrational psychological accents of the electorate, which are political faith and mythmaking, on the basis of the analysis of information broadcasted by means of mass dissemination (television and electronic).

In turn, the definitive count of the elections made it possible to evaluate the level of intellectualization of Ukrainian society or its saturation of Ortega y Gasset's "mass man", who is uncritically oriented towards political faith.

The theoretical and methodological basis of this study are laid by philosophers and other scientists of humanities of this and the last century, who carefully investigated the phenomena of spiritual impoverishment and deintelectualization of society, its transforming into the already mentioned "mass", the specific features of which are the consumption of information, the inability and unwillingness to verify this information, penchant for products of mass and affectively saturated culture. Fundamental works of, in particular, J. Ortega y Gasset (1994), H. Spencer (1999), A. Gramsci (2005) were devoted to it.

Various aspects of influence on the "mass", the formation of predetermined values, political or marketing pre- 
ferences through manipulative practices are also wellresearched by the scientists of the 20-21st centuries. An example of such researches is the classic "Mind Manipulations" by S. Kara-Murza (2005), or little known to the domestic reader "Prison Notebooks" by mentioned above Antonio Gramsci. In general, this depressing and primitivizing influence, hidden from the masses, is carried out on the affective sphere and mental processes by various tools. The manipulator seeks to form a political myth, which is structured by the samples of subconscious constructs identified in particular by C. G. Jung (1996a; 1996b), J. Campbell (1997), M. Eliade (2000; 2010), V. Propp (2001), in the mass consciousness. It should be noted that the cohort of domestic scientists has recently carefully considered the course of such manipulation against the background of the hybrid war against Ukraine within the framework of the research work "Social and philosophical reflection of the ways of resolving the conflict in the East of Ukraine" (state registration №011U002518) (Dodonov (ed.) and other, 2017).

Along with this, the scientific exploration presented here is one of the first modern domestic works on this subject, which additionally determines its relevance.

\section{Methods}

The degree of rationality of advertising political flows was evaluated with observation and comparison involving classical formal logic. The latter, being the traditional sphere of philosophy, is especially suitable to evaluate the "maturity" or "immaturity" of the language flow and specially of political rhetoric. It had developed general laws, signs of right thinking, numerous rules of operations with a conceptual apparatus, criteria of truth of statements, logical consequences, rules of civilized discussion, which are traditional for a developed democratic politics. There is probably no need to acquaint aware and educated reader with this array of formal and logical norms, because the subject "Logic" was excluded from the list of compulsory subjects by our Ministry of Education and Science not so long ago.

Elements of mythmaking were revealed with the similar method. The theoretical, particularly philosophical aspects, outlined in works of the classics mentioned about, allow easy and prominent distinguishing of myths or attempts to construct political quasi-religious accents. Therefore, knowing the defining features of the latter two, namely, the sequence of compulsory components of the myth, their algorithm and completeness, emotional substance and appealing to the faith, it was not difficult to trace political opponents in activities of teams.

\section{Results and Discussion}

During the analysis it appeared that none of the candidates for the Ukrainian presidency or their teams built or exploited a scientifically shaped myth about themselves. It clearly characterizes them pretty much like dilettantes. Ignoring the fact that mythmaking is exactly the basis of any human activity is anti-scientific.

J. Campbell, mentioned above, in "The Monomyth", the first section of his famous work advocates the thesis "It would not be too much to say that myth is ... opening through which the inexhaustible energies ... pour into human cultural manifestation. Religions, philosophies, arts, the social forms ..., prime discoveries in science and technology ... boil up from the basic, magic ring of myth" (Campbell, 1997). Equal positions were articulated by S. Freud, C. G. Jung, E. Neumann, D. Gilman and other thinkers.
The above-mentioned fundamental analysts of the myth have repeatedly emphasized that the myth is impossible without specific stages, for example, Meeting the Harbinger, Escape, Transition, Transformation, Gain, Return. It is clear that such a directing should be saturated with mythologems, emotionally rich fragments of a holistic history. We shall notice that for the generation of a temporally stable myth these stages cannot be ignored and their algorithm cannot be altered. Moreover, it is even dangerous for the public image of the person who is mythologized.

Most candidates probably expected that certain original features - a pretentious political slogan on the poster, a change in the shape of glasses, makeup, hairstyles, hair color, the degree of unshaveness on the promotional photo, etc. - would have a positive effect on a voter. But from the point of view of achieving a stable long-term result it is unproductive. Without a basic axial myth, which, we should repeat, is absent among competitors, these or other elements would stick together and remain in the voter's mind or subsequently might even disgust.

Along with this, only one candidate, who until recently has been known as an artist of popular genres, is out of this picture. Instead of the classical myth of leader (supposedly), a really high-quality and original cinematic simulacrum was created about him.

A famous actor plays the role of fictional President V. Holoborodko in the television series "Servant of the People". It is clear that the series contains a holistic and skilfully constructed myth about the difficult development of $\mathrm{V}$. Holoborodko as a politician. This myth is entirely consistent with the classical direction of the unconscious. It is hardly surprising that the irrational mass-man naturally associate the actor with a fictional person who is an experienced and rather decent politician, despite the fact that the comedian himself lives not in that way in reality and has no political experience.

Here we have to assume that the mentioned series, probably, was specially created for the actor's political mythologization, since it was broadcasted directly before the election campaign and during it, accustoming the viewer to the myth and, accordingly, positively affecting ratings of $\mathrm{V}$. Zelensky. Therefore, this movie de facto is a political advertisement of the latter, because the "man of the masses" does not see the difference between the illusory role and the real comedian, between the pretentious imitation on the screen and the real presidential duties.

The author gives proper respect to the ingenuity of the authors of this political engineering invention - to substitute the classic political myth for the constructed cinema-myth of a fictional, non-existing person. Its effectiveness is obvious - the actor who played a role and was not a specialist in the areas of politics, economics, management, had a dominant rating and won the presidential race.

Let us return to the main idea of the classification of the flows of modern political agitational rhetoric under the criterion of rational maturity. We would like to state that, besides the famous actor, other contenders for the presidency hardly used the myth. Other political players really (and strategically mistakenly) by their speeches and interviews sought to focus on a rationally mature layer of Ukrainian citizens who would attempt to at least verify the myth.

So, at first glance, we have a dichotomy of agitation that appeals to the myth or to rationality. But, in our opinion, it should be clarified with intermediate types of appeal of candidate politicians. We give them below: 
Appeal to the rational thinking of the voter. The main characteristics of the politicians who demonstrated it are clarity, unambiguousness and consistency of speech, the ability of independent "live" mostly meaningful speeches, reasoned answers, discussions, debates, etc. The relaxedness and flexibility of communication of such political figures, their direct meetings with the electorate in different regions of the state, the tendency towards laconicism, the demonstration of real, rather than fictional achievements, demonstrate the certainly high rational culture of such candidates. But, in author's opinion, there are few representatives of this type.

Appeal to the literate mythmaking. There are also few of them. Except the mentioned actor, almost nobody has created a harmonious in terms of philosophy and psychoanalysis myth of "oneself".

Here we should notice that a number of candidates sought to associate themselves with the mythmaking which was carefully developed in Soviet times. They articulated the myths about the "fraternal peoples", "one people", "the great family of people", etc., and won the sympathy of a certain part of the electorate. But since this mythology is outdated, sympathy for these people does not dominate.

Appeal to episodic (illiterate) mythmaking. The majority of candidates tried to fluctuate between rational influence on voters and the use of individual elements of mythmaking - a mythologeme. It is not difficult to identify such people, because they are forced to demonstrate template agitational statements. In other words, the Hero of the myth develops in an agitational product, and, accordingly, in the imagination of "man of the masses". He is not static. Rational person is not static as well, because such person meets the dynamically changing conditions. And the person who represents a limited number of fables-mythologemes is forced to use template statements. For example, they stigmatize themselves solely as "honest" or "victims" of "criminal power", etc. Or they ascribe themselves the achievments of the current (at the moment of writing the article) President of Ukraine - such as: strengthening the country's defense capability, reforming the police or the armed forces, lethal weapons transfer from abroad, creating a single local church, extending the regime of sanctions against Russia, etc. They acted as if it was initiated not by the President, but by a particular "he" or "she".

Such deception of voters is also episodic mythmaking, because it operates through emotionally rich stories that pretend to be "undeniable fact" but may not correspond to reality at all. It is interesting that, on the basis of the logic of our research, such template artificial false constructs that exploit the achievements of great politicians should always be expected.

Speaking about the behavior of this type of candidates, then, fearing rational questions, they are reluctant to meet with impartial journalists, avoid direct meetings with the electorate or simulate these meetings, preparing in advance the special actors for the television "picture". Their statements are predictable and saturated with branchy accusations, self-approvals and slogans. All political opponents are painted in emotional negativity, and the personality of person who speaks is, on the contrary, romantically or sentimentally heroized.

Those who appeal only to faith. Such candidates offer voters "to trust", "to believe" in them. Such words are the basis of their rhetoric. They do almost without mytho- logemes and without the use of lie. They do not offer rationally verified evidence, arguments, algorithms for achieving promises, but they also do not resort to branchy mythologization. Candidates seek to awaken the uncritical political voters' faith and currently have a very low electoral rank in Ukraine. They would hypothetically have a high rank only in the transition to the second (higher) taxonomic class, i.e. with a mythologization of their personalities.

\section{Conclusions}

Summarizing the foregoing, we can state the following.

1. We can classify the flows of modern political agitational rhetoric on the criterion of rational maturity or orientation to the myth or solely on faith with distinguishing at least four varieties. It is clear that the presented division is rather conditional and may be discussed in details. There are very little number of representatives of two "pure" taxonomic types and this led to a contrasting division of respondent-voters in the presidential election in Ukraine.

2. A moderate domestic politician today and in the near future should understand the objective extent of the "man of the masses" that constitutes the clear majority among citizens. It means that reliance purely on support of critically minded people is false and hopeless in terms of the electoral success.

3. Uncriticality combined with the inhomogeneity of the audience objectively dictates the special task to the subjects of political activity - to convey their thoughts, visions, emotions and feelings to as many listeners, who are people of all ages, sex, profession, education, level of general and intellectual culture, as possible. Solving this task, the majority of agitational flows of literate political players should engage all the useful, efficient and effective that have been presented on these elections. In other words, even without wanting, the politician must, should resort to scientifically constructed myths without losing rational attitude to their promises in the electoral programme. Because reliance on the myth is appropriate in presidential race, and after it the implementation of the promised is the obligation of a responsible rationally thinking person and a key to the people's support.

4. We should also note here that no less important than the creation of a correct myth-agitational advertising product and the rational construction of the program in the future political campaigning is a factor in their powerful broadcasting, both by the media and informal channels, for example, rumors, anecdotes, etc. In the absence or weakness of distribution of these works to the public, the man of the masses simply will not be familiar with them and not "accustomed" to them.

Therefore, the Ukrainian choice made by voters in the spring of 2019, on the one hand, is an objective and sad marker of the mental immaturity of our nation, in which there is a significant percentage of the "man of the masses", and, on the other hand, it gives a good factualanalytical ground for creative formation and mass distribution of agitation products of politicians of the near future.

\section{REFERENCES}

Biletskyy, V. V. (2006). Formalna lohichnist politychnoyi rytoryky yak tekhnolohiya vplyvu na elektorat. In: Materials of the second scientific conference "Modern social problems in the measurement of sociology of management" (Donetsk, April 14, 2006). Donetsk: DonNUU: 192-195. (In Ukrainian)

Biletskyy, V. V. (2010). Aktualnist prykladnykh doslidzhen 
politychnoyi rytoryky. In: Materials of the Regional Scientific Conference "Philosophy in the Modern World". Donetsk: DonNU: 74-75. (In Ukrainian)

Ortega y Gasset, José (1994). Bunt mas (translat.) In: Vybrani tvory. Kyiv: Osnovy. (In Ukrainian)

Spencer, Herbert (1999). Opyty nauchnyye, politicheskiye I filosofskiye. Minsk: Sovremennyy literator, 1408 p. (In Russian)

Gramshi, Antonio (2005). Tyuremnyye tetradi (translat.). In three parts. Part 1. Moscow: Izdatelstvo politicheskoy literatury, 560 p. (In Russian)

Kara-Murza, S. (2005). Manipulyatsiya soznaniyem. Moscow: Eksmo, 832 p. (In Russian)

Eliade, Mircea (2000). Izbrannyye sochineniya. Mif o vechnom vozvrashchenii (translat.). Moscow: Ladomir. 414 p. (In Russian)

Eliade, Mircea (2010). Aspekty mifa (translat.). Moscow: Akademicheskiy proyekt, 256 p. (In Russian)

Yung, K. G. (1996a). Chelovek i yego simvoly (translat.). St. Petersburg: B. S. K., 451 p. (In Russian)

Yung, K. G. (1996b). Dusha i mif: shest arkhetipov (translat.) Kyiv: State Library of Ukraine for the Young, 384 p. (In Russian) Campbell, J. (1997). Tysyachelikiy geroy (translat.). Moscow: Vakler, Refl-buk, AST, 384 pp. (In Russian)

Propp, V. (2001). Morfologiya volshebnoy skazki. Moscow: Labirynt, 114 p. (In Russian)

Dodonov, R. O. (ed.) (2017). Hibrydna viyna: in verbo et in praxi. Vinnytsya: TOV "Nilan- LTD", 412 p. (In Ukrainian)

\section{LIST OF REFERENCE LINKS}

Білецький В. В. Формальна логічність політичної риторики як технологія впливу на електорат. Матеріали другої наукової конфреренції "Сучасні суспільні проблеми у вимірі соціо- логії управління" (Донецьк, 14 квітня 2006 р.). Донецьк, ДонДУУ, 2006. С. 192-195

Білецький В. В. Актуальність прикладних досліджень політичної риторики. Матеріали регіональної наукової конференції "Філософрія у сучасному світі". Донецьк: ДонНУ, 2010. C. $74-75$.

Ортега-і-Гасет Х. Бунт мас. Ортега-і-Гасет X. "Вибрані твори". Київ: Основи, 1994.

Спенсер Герберт. Опыты научные, политические и философские. Минск: Современный литератор, 1999. 1408 с.

Грамши Антонио. Тюремные тетради. В трех частях. Часть 1. Москва: Издательство политической литературы, 1991. 560 c.

Кара-Мурза С. Манипуляция сознанием. Москва: Эксмо, 2005. 832 c.

Элиаде Мирча. Избранные сочинения. Миф о вечном возвращении. Москва: Ладомир, 2000. 414 с.

Элиаде Мирча. Аспекты мифра. Москва: Академический проект. 2010. 256 с.

Юнг К.-Г. Человек и его символы. Санкт-Петербург: Б. С. К., 1996. С.451.

Юнг К.-Г. Душа и миф: шесть архетипов / пер. с англ. Киев: Государственная библиотека Украины для юношества, 1996. 384 c.

Кэмпбелл Дж. Тысячеликий герой. Москва: Ваклер, Рефрлбук, АСТ, 1997. 384 с

Пропп В. Я. Морфология волшебной сказки. Москва: Лабиринт, 2001. 114 с.

Гібридна війна: in verbo et in praxi: монографія / Донецький національний університет імені Василя Стуса; за. заг. ред. Р. О. Додонова. Вінниця: ТОВ "Нілан-ЛТД", 2017. 412 с.

Білецький Віталій,

Донецький національний університет імені Василя Стуса (м. Вінниия, Украӥна)

e-mail: beleckii-vitalii@mail.ru,ORCID 0000-0003-2818-131X

\section{ПОЛІТИЧНА АГІТАЦІЯЙ СТАН МЕНТАЛЬНОї ЗРІЛОСТІ ВІТЧИЗНЯНОГО СУСПІЛЬСТВА}

У статті автор розробляє варіант типологізації акцентів впливу на вітчизняний сучасний електорат під час виборів Президента України навесні 2019 року. Ця мета досягається шляхом залучення соціально-філософської методології й надбань психоаналітичної філософської парадигми. Виділено чотири типи таких акцентів, які простежувалися протягом перегонів. Політичні особи, що дотримувалися першого типу впливу, прагнули оперувати з критичним мисленням виборців. Друга група політиків прагнула використати науково сконструйований міф - про себе або "майже" про себе. Третя група зосереджувалася на індивідуальних міфах, які не об'єднані цілісним політичним міфом. Четверта група апелювала до нерозумної довіри. Вони утворюють континуум - від намагання вплинути суто на раціональність виборця до розрахунку на резонанс його підсвідомої міфологічної архітектоніки. Крім цього робиться висновок про те, що політик найближчого майбутнього повинен гнучко залучати все конструктивне з цього континууму для посилення власного позитивного впливу на електорат.

Ключові слова: вибори Президента України; електорат; раціональність; логічність; політична міфротворчість; міфрологема.

(C) Biletsky Vitaliy

Надійшла до редакції: 02.05.2019

Прийнята до друку: 07.06.2019 